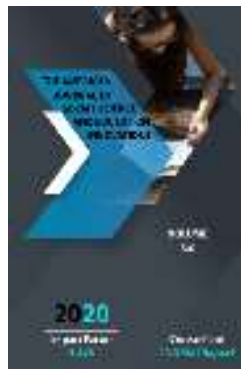

Journal Website: http://usajournalshub.c om/index,php/tajssei

Copyright: Original content from this work may be used under the terms of the creative commons attributes 4.0 licence.

\section{Note Design Of Khorezm Makoms And Mutual Integration Of Music With Fine Arts}

\author{
Samandar Kuzievich Khudaibergenov \\ Professor, Department Of Music Education, Urgench State University, Urgench, Uzbekistan \\ Diyarbek Janibekovich Khaitbaev \\ Senior Lecturer, Department Of Fine Arts And Engineering Graphics, Urgench State \\ University, Urgench, Uzbekistan
}

\title{
ABSTRACT
}

The paper is dealing with fret construction of Khorezmian makoms and its common structure Comparative analysis of Bukharian and Khorezmian makoms had been made. The conclusion about main styles of makoms are given also.

\section{KEYWORDS}

Khorezmian makom, Bukharian makom, maqomat, shashmakom.

\section{INTRODUCTION}

Recently, serious changes have been observed in the study of the internal sides of the general structure of the maqomat and its individual species - Bukhara shashmakom, Khorezm maqoms and Fergana-Tashkent styles. In particular, new directions are clearly observed in the study of the constituent foundations of the modal structure in the philosophy of maqom. [1]
O. Matyakubov's book "Makomat" pays much attention to the scientific and theoretical side of modal structures. In our article, proceeding from the principles described in the book "Makomat", we intend to set out some considerations on the modal structure of the Khorezm maqoms. 


\section{MAIN PART}

The author of the article at one time tried to learn the basics of maqom from the teachers of the conservatory, famous Hafiz masters and musicians. Comparing the knowledge and skills gained with the knowledge given in the scientific works of musicologists, we come to the conclusion that the components of the modal base of the maqom are of paramount importance in the formation of a consistent structure of other stylistic qualities of maqommethods, form, performance and interpretation.

For example, two great khafiz Khadzhikhan Baltayev and Kamiljan Ataniyazov with poppy seed "Segoh", each performed in their own way. There are significant differences in their performance of usule, vazn (meter), melodic phrases, and in general, maqom constructions. But in the performances of these two great masters, the modal base is the same. That is, in the formation called "Segoh", the mode and melodic structure are preserved thoroughly. [3]

From the scientific and practical point of view, this issue was first covered by the singermaster Azad Ikramovich Ibragimov. Fortunately, A. Ibragimov is a singer who went through the performing school of Khadjikhan Baltaev and Kamiljan Ataniyazov, who accompanied them on the doira, and in some cases sang with them. That is, he learned these services from real sources. Therefore, what he heard, assimilated and brought to us is very important.

Now let's return to the problem of the fret, which was raised at the beginning of our article, and begin our reflections with the analysis of the "Segoh" maqom. It is known that the questions of the harmony in musicology are connected by complex theoretical concepts. We do not have the opportunity to consistently enter this problem and analyze it more deeply, therefore it is advisable for us to observe the construction of the harmony "inside", from the point of view of the performer-trainee. In the article, from this point of view, the construction of the mode is analyzed, and first of all, according to the scale, the sound table. The scale is only one of the sides of the modal structure, to put it even more simply, it is the general scheme of the modal structure. In the problem of the scale, the most difficult place is the designation of small frets in the notes. Everyone knows that the European musical notation system is based on the temporated twelve semitone system. In the modes of maqom, in addition to these temporated semitones, there are more and fewer tones. [ 2 ]

Ulmas Rasulov calls the units different from these semitones - "colored frets". Because these frets denote the sound color palette of each maqom. The general sound table of the "Segoh" maqom is given in the book by AtanazarMatyakubov

“Makomat":Segoh-note.

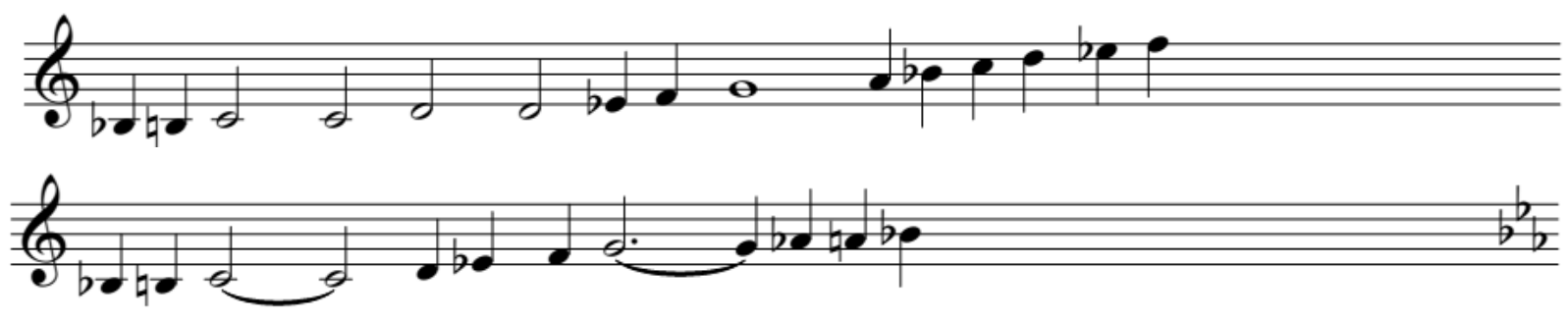


The American Journal of Social Science and Education Innovations

(ISSN - 2689-100x)

Published: October 21, 2020 | Pages: 97-102

Doi: https://doi.org/10.37547/tajssei/Volumeo2Issue10-15

Segoh-note performed by Khadzhikhan Baltaev and Kamiljan Ataniyazov in rhythmic and compound structures, no matter how different from each other, they still do not go beyond this modal structure. It is their creative approach to the performance of "Segoh" that has a huge success among fans.

An important aspect of the issue is that "Segoh", performed at one time by Abdusharif Vafaev, Ruzmat Jumaniyazov and Atajan Khudayshukurov, did not seem to differ from each other, although they were based on "Segoh" anyway, that is, the stable mode of execution did not change ... And this is evidence that the miracle art called maqom is eternal and its eternity is based on these fundamental laws and the balance of creative freedoms. [12 ]

It is known that the maqoms in Bukhara and Khorezm developed in two main directions. If one of these directions was spread among a narrow circle of fans, then the second consists of makoms (practical), performed in wider circles. These directions in Bukhara were called "Shashmak" and "Shubachalar", and in Khorezm "Tanburne" (Six and a half maqoms) and "Dutar maqoms". It is known that the main Shuba melodies of Bukhara maqoms are mostly called by common names.

For example, Sarakhbori, Buzruk-Mugulchai Buzruk, Nasri ushshok-Savti ushok, Sarakhbori navo-Mugulchai Navo, Nasri Bayot-Mugulchai Bayot, etc. And in the Khorezm maqoms, on the contrary, the Dutar and Tanbur maqoms, even if they belong to the same modal system, we observe their distribution under different names. For example: "Buzruk" in tanburne maqom and "Orazibom" and in the category of dutar maqom are very similar in scale. If we compare their sound table, we will see their commonality.

Buzruk Orazibom ladi.
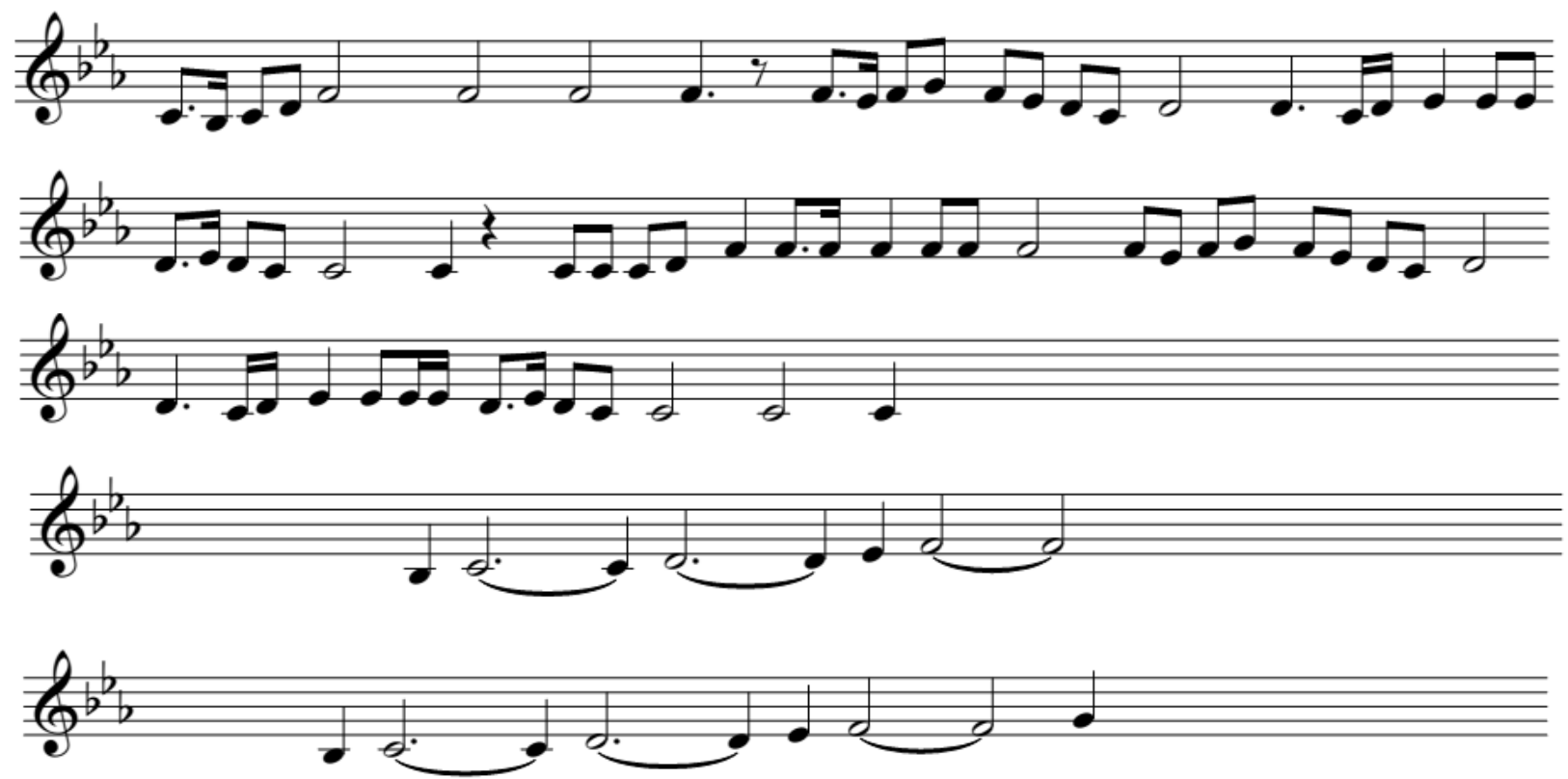

But the sound table is not a melody yet. But if we carefully follow the melodic lines of "Buzruk" and "Orazibom" by Tanya makom,

we will see that there is a similarity in the sounds of his sound and motor grounds. [ 2 ] 


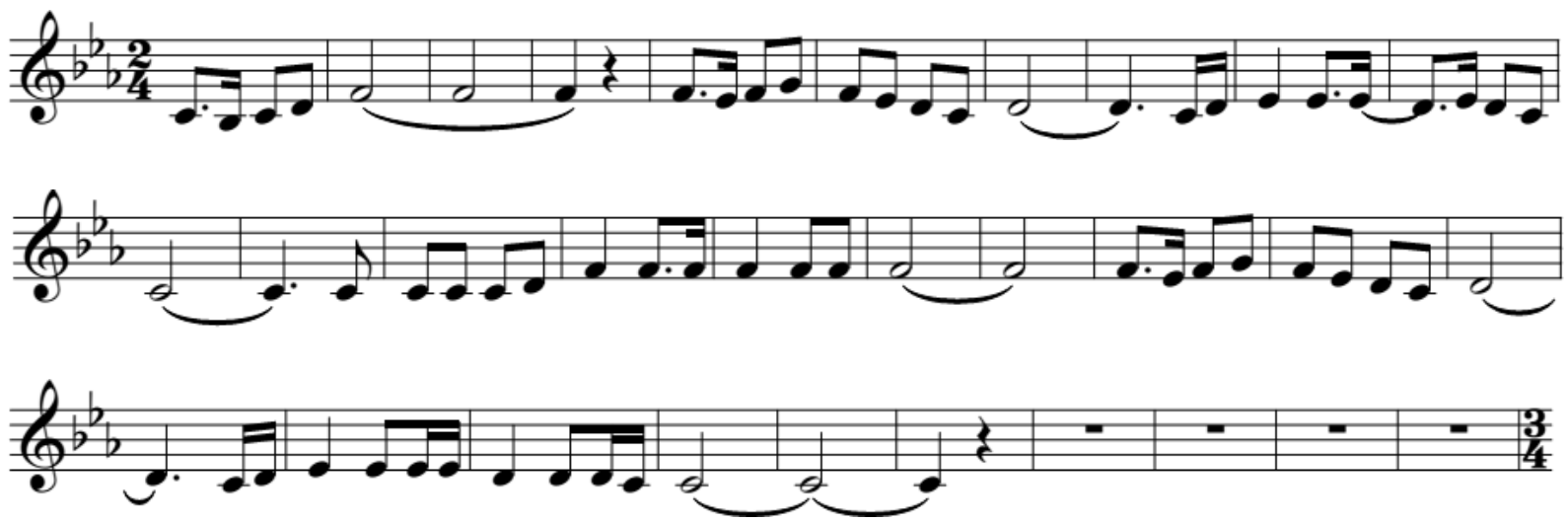

There are similarities between "Growth" in Tanburny maqom and "Zikhi Nazzor" in Dutarny maqom, as well as between "Buzruk" and "Orazib". first place. When the songs and melodies are analyzed in the maqom category, first of all, their compliance with strict rules is noted. And here the correspondence between "Rost" and "Zikhi Nazzor" is apparently not unreasonable. [1]

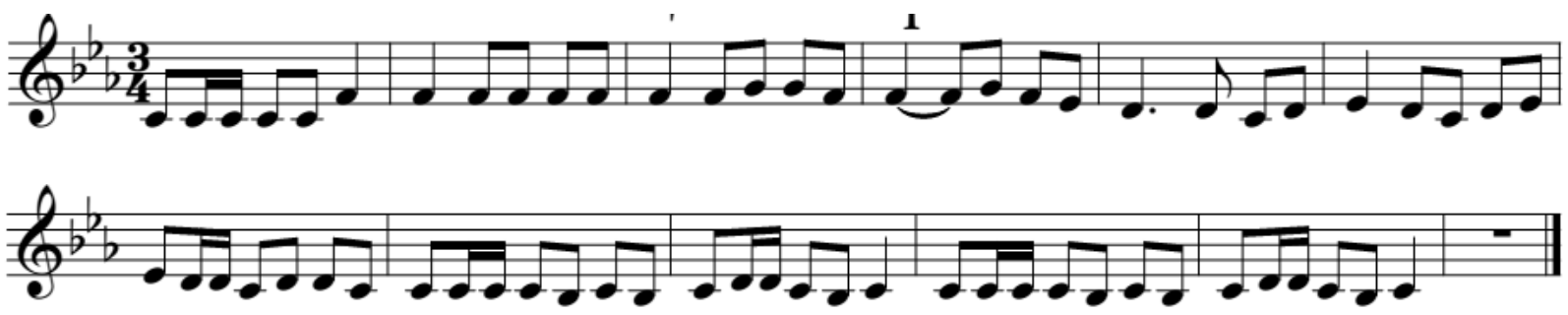

The sense of color is a reflection of folk art culture. In humans, the perception of color is individual, which depends on the person's gender, age, mood, life experience and many other factors. However, a lot can be found in the perception of color in different people. [ 8 ]

You can think and design with color. Color can give shape to an object, describe the beauty of the environment, reflect emotions, mood, a clear emotional state.

Let's take a look at another aspect of the magic power of color. He is different arises from the interaction of the arts.
Art within groups can also unite. It is a combination of plastic art and temporary art. Synthesis in the plastic art group is based on architecture. It often combines music, painting, graphics, arts and crafts, or design.

A synthesis of arts belonging to different groups is also possible. Here are some examples. For example, the design sought to blend in with the music, while reflecting different - hazy outlooks on life. The influence of sheet music design on painting, graphics and sculpture began with the fact that various forms of musical perception (writing poetry, listening to music, performing) inspired artists and gave them a theme to create a piece. The images created in antiquity, as well as relief 
images, reflect various customs and traditions, holidays and celebrations of the horns, in which we see that musicians are also depicted. [16]

In ancient Greek art, you can also find images of musicians playing music in theatrical performances and sports competitions. Such paintings are not limited to reliefs or drawings on buildings. but can also be found in paintings on flower pots.

If we look at history, we will see that the ceremonies held in the Gothic cathedral made a very strong impression on people. The sound of the choir and organ, performed at the ceremony, harmoniously combined with the light passing through the stained glass windows. All this has formed an artistic integrity.

During the Middle Ages and the Renaissance, painting and sculpture often depicted angels singing and playing the flute, folk singers and musicians on holidays, dancers or musicians playing the valinka, violin, harpsichord and viola. In ancient times, the allegorical image of the patron saint of music, Musa, was depicted with some kind of musical instrument.

Musical and pictorial design primarily combines the content of ideas, images, drama, emotions. In addition, instruments such as composition, rhythm, harmony, dynamics, color are important. The result is a synthesis of both arts. True synthesis in art can create a real miracle.

In the 19th - 20th centuries, the direction of "music" developed in painting. V.M. Vasnetsov said this "I've always wanted to feel music in my paintings." The artist A. Savrasov knew how to feel and describe the music of Russian nature in his paintings.

For example, in his work "Black Crows Are Flying", you can feel the spring music. In it you can hear the sound of drops, the rustle of water, the rustle of birch branches, the crowing of crows.
Vrubel, M. Churleni managed to give their paintings a mutual harmony of color and sound. M. Čiurlionis named his paintings "Prelude" and "Sonata".

The imaginative world of Čiurlionis is a wonderful combination of these dreams, harmony and fantasy. He wrote such works as "Spring Sonata", "Summer Sonata", "Sunny Sonata", "Star Sonata", "Snake Sonata", "Pyramid Sonata". The sections of each sonata are named in musical terms (Allegro, Andante, Scherzo, Finale). Each picture has a clear mood, a sense of lyrics. Rhythm played an important role in these paintings, for example, in the "Sea Sonata" the rhythms are different. It has the rhythm of waves, ships, waters, shores.

Composer A. N. Skryabin presented his works to the audience in collaboration with colored lighting. Music and colorful lighting created a holistic image. [14 ]

By the nineteenth century, the idea of synthesizing music, color and light had become very common. For example, in many cities around the world, singing, colorful musical fountains have been built. In it, musical notes, watery rhythm and color scheme complement each other. Without music, this work of art loses its figurative meaning.

These new forms in the modern avant-garde direction are based on dialogue and communication between the artist and the public.

\section{CONCLUSION}

We have considered some examples belonging to the Khorezm maqoms. Based on these examples, we can make the following conclusion: these styles of makom, unlike other classical melodies and songs, are based on a strictly defined modal structure.

The fret system of the tanbourne and dutar maqoms has not been fully studied in modern musicology. Studying it scientifically is a 
challenge for the new generation of master singers.

\section{REFERENCES}

1. Yusupov. M. Khorezm maqoms. Tashkent. 1958.

2. Matyakubov. A. Makomat. Tashkent. 2004.

3. O. Matyakubov. Khorazm dutor maqomlari va olti yarim maqomi. Toshkent. 2018.

4. Xo'jamqulov P.B., Mamedyarov T.X. Xorazm maqom san'atiga bir nazar. Angren 2008-yil.

5. Bo'riyeva K. An'anaviy xonandalik (ayollar ovozlari uchun) Akademik litsey va kollej o'quvchilari uchun o'quv-uslubiy qo'llanma Toshkent. 2008-yil.

6. Matyoqubov O. Xorazm dutor maqomlari va olti yarim maqomi.

Toshkent 2018-yil

7. Hayitmetov A. Alisher Navoiy (1441-1501). http://e-adabiyot.uz /uzbek/mumoz/1119maqola.html

8. Jalilov Marim. Qo'shiqlar xrestomatiyasi. 2-kitob. Toshkent, 2003.103 bet.

9. Sharipova G.M. Musiqa va uni o'qitish metodikasi. Toshkent. "Turon-iqbol". 2011.167 bet.

10. Razhabov I. Maqomlar. "Sanat" nashriyoti. Toshkent. 2006.273-278betlar.

11. Akhmadeeva Ya, The main directions of development of art education in Mexico // Art school-M, 2003.-№3C24-28,0,25pl.

12. Devyatkina O.Yu. Modern pedagogical technologies. [Electronic resource]: Social network of educators nsportal.ru. Exit mode: https://nsportal.ru shkola obshchepedagogicheskie tekhnogii library 2012/01/09 / modern pedagogical technologies // (access data: 06/02/2019).

13. Druzhkova NI, Higher School in Ulm (19531968) [Electronic resource] // Institute of Art Education and Cultural Studies of the Russian Academy of Education: [site]. URL: http://www.art- education.ru elektronika-journal higher education school-v-ulme-1953-1968 (entry dated 05/04/2018).

14. Zhdanova NS, Press: textbook - Publishing house "Aspect Press" -2018 - ISBN: 97857567-0926-1-Electronic text // EBS LanURL: http://e.lanbook.com book112497.

15. Zhdanova NS, Fundamentals of design and design and graphic modification: textbook // NS Dzhanova.-Moscow, FLINT, 2017. -196 p. -ISBN 978-5-9765-3397-4. -Friends

16. Zadresenets E.E., Sergeeva G.K. Innovations and industrial design [Electronic resource] // Design review: [site]. URL: http: designreview.netindex.php Show article ID 172 ear 2006 \# 3 (accessed: 05/07/2018).

17. London Institute of Printing (London College of Printing) [Electronic resource]. - Access mode: http://www.ncl-coll.ac.uk.

18. Maron $A E$, Scientific foundations and approaches to the construction of models of professional and personal growth of a teacher A. E. Maron L. V. Rezinkina // Man and education. - 2018. - No. 2 (55). - S. 16-21.

19. Mirzoyan SV, Formation and development of the St. Petersburg school of industrial design: late XIX - early XXI century: Author. Doctor of Medical Sciences: 17.00.06. SPb.: 2017.51 b.

20. Murtazina SA, History of art before the historical epoxia and ancient world: Text of the lecture by SA Murgazin.-Kazan .: Kazan Publishing House, State Texnol.unta, 2007.-84p. 